10.15290/cnisk.2019.02.07.12

DR MARCIN SIEDLECKI

Państwowa Wyższa Szkoła Informatyki i Przedsiębiorczości w Łomży

\title{
Instytut Studiów Kobiecych i jego działalność \\ w zakresie badań naukowych historii kobiet \\ i ich upowszechniania (2017-2019)
}

\section{Streszczenie}

Instytut Studiów Kobiecych (ISK), pomimo relatywnie niedługiego okresu funkcjonowania (zał. 2011), aktywnie i skutecznie realizuje cele statutowe w zakresie prowadzenia, upowszechniania i popularyzacji badań naukowych dotyczących historii kobiet. Szczególnie owocne przejawy działalności ISK sa zauważalne w latach 2017-2019, w których stowarzyszenie organizowało krajowe i międzynarodowe konferencje naukowe, wzięło udział w zagranicznych wizytach studyjnych, rozwijało własne wydawnictwo (Wydawnictwo Humanica) i periodyk naukowy („Czasopismo Naukowe ISK”) czy wreszcie zainicjowało Białostocka Szkołę Historii Kobiet. Działalność stowarzyszenia w obszarze badań naukowych historii kobiet wkomponowuje się w krajowy (i szerzej międzynarodowy) nurt wzmożonego zainteresowania tematyką kobieca sensu largo, uzewnętrzniająca się m.in. skokowym wzrostem pozycji wydawniczych dotyczacych dziejów kobiet.

Słowa kluczowe: Instytut Studiów Kobiecych, historia kobiet, popularyzacja badań naukowych 


\title{
INSTYTUT STUDIÓW KOBIECYCH [INSTITUTE OF WOMEN'S STUDIES] AND ITS ACTIVITIES IN THE FIELD OF RESEARCH INTO WOMEN'S HISTORY AND ITS DISSEMINATION (2017-2019)
}

\begin{abstract}
Instytut Studiów Kobiecych, ISK [Institute of Women's Studies], despite a relatively short period of operation (est. 2011), actively and effectively implements its statutory objectives in the field of conducting, disseminating and popularising scientific research on women's history. Particularly fruitful manifestations of ISK's activity are noticeable in the years 2017-2019, when the association organised national and international scientific conferences, took part in foreign study visits, developed its own publishing house (Humanica Publishing House) and a scientific periodical (Czasopismo Naukowe ISK, Scientific Journal of the Institute for Women's Studies) and finally initiated the Bialystok School of Women's History. The association's activities in the area of research into women's history blend in with the current national (and more broadly international) increased interest in the women's issues, in the broad sense, manifested, inter alia, by a sudden increase in papers published on the history of women.
\end{abstract}

Keywords: Instytut Studiów Kobiecych, Institute of Women's Studies, women's history, popularisation of scientific research

Przegląd bazy bibliotecznej uwzględniajacej połaczone zbiory Biblioteki Narodowej, Biblioteki Jagiellońskiej, Wojewódzkiej Biblioteki Publicznej im. Hieronima Łopacińskiego w Lublinie oraz Wojewódzkiej Biblioteki Publicznej im. Witolda Gombrowicza w Kielcach informuje o 17,5 tys. pozycji ${ }^{1}$ zawierajacych w temacie frazę "historia kobiet”2. Czytelnicy ww. instytucji kultury poza pozycjami wydanymi w jezzyku polskim moga również odnaleźć jednostki czytelnicze w językach angielskim (28\% wszystkich), niemieckim (4,2\%), rosyjskim (3,9\%), francuskim (3,5\%). W ujecciu przedmiotowym prace poruszajace tematykę dziejów kobiet dominuja w następujacych dziedzinach (działach): histo-

\footnotetext{
1 Pod nomenklatura „pozycja biblioteczna” sa rozumiane: artykuły, albumy, audiobooki, czasopisma, e-booki, ksiażki, eseje, wydawnictwa publicystyczne, publikacje naukowe i popularnonaukowe, wydawnictwa literackie, a także mniej powszechne inne formy przekazu gromadzone przez sieć bibliotek wskazaną w artykule.

2 Zob. https://katalogi.bn.org.pl/discovery/search?query=sub,contains, historia kobiet.
} 
ria (26,7\% zbioru), socjologia i społeczeństwo (9,5\%), kultura i sztuka $(9,3 \%)$, politologia i administracja publiczna $(8,6 \%)$, religia i duchowość (4,5\%). Wśród pozycji bibliotecznych ponad połowa to artykuły (łącznie 8,5 tys.), w tym: problemowe (1733), z czasopism naukowych (1119), publicystyczne (1060), z prac zbiorowych (1075), z tygodników opinii (559), z czasopism społeczno-politycznych (510). Poza artykułami tematyka dziejów kobiet pojawia się powszechnie w wywiadach dziennikarskich (735 pozycji), biografiach (657), recenzjach (460), opracowaniach (323), materiałach konferencyjnych (245).

Wykres 1. Liczba pozycji bibliotecznych zarejestrowanych w bazie połączonych katalogów Biblioteki Narodowej, Biblioteki Jagiellońskiej oraz kieleckiej i lubelskiej Wojewódzkiej Biblioteki Publicznej dotyczacych „historii kobiet” według roku wydania

$$
2500
$$

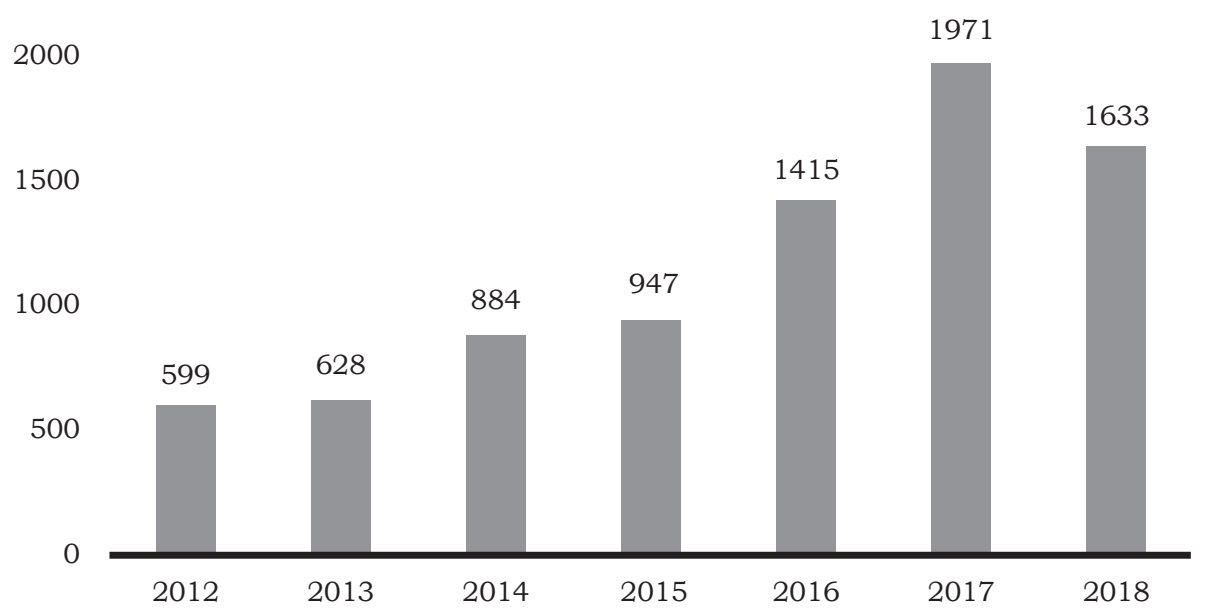

Źródło: opracowanie własne na podstawie danych z katalogów Biblioteki Narodowej, https://katalogi.bn.org.pl.

Popularność zagadnienia historii kobiet w materiałach wydawanych i udostępnianych otwartemu gronu odbiorców to domena ostatniej dekady. Spośród 17,5 tys. pozycji bibliotecznych dostępnych w połaczonej bazie BN-BJ oraz lubelskiej i kieleckiej WBP aż 9,8 tys. (56\%) 
to pozycje wydane w latach 2010-2019³ .Pik” wydawniczy poświęcony historii kobiet zanotowano na krajowym rynku czytelniczym w 2017 r., w którym to pojawiło się niemal 2 tys. pozycji bibliotecznych tematycznie powiąanych $z$ fraza „historia kobiet”. W latach 2017-2019 (cezura czasowa przedmiotu niniejszego artykułu) wydano aż 4270 prac powiązanych $z$ tematem dziejów kobiet, czyli de facto $1 / 4$ wszystkich pozycji dostępnych użytkownikom sieci bibliotecznej BN-BJ-WBP Kielce-WBP Lublin, zainteresowanych słowem pisanym, mówionym (audiobooki) lub zbiorami ikonograficznymi - wydanych od 1752 r. (od roku wydania starodruku La science des personnes de cour, d'epée et de robe/ commencée par Mr. de Chevigni; continuée par Mr. de Limiers; revue, corrigée et considérablement augmentée par Mr. Pierre Massuet, pracy dotyczacej szermierki, identyfikowanej przez system sieci bibliotecznej jako najstarsza powiazana $z$ fraza „historia kobiet”).

Instytut Studiów Kobiecych, funkcjonujący od 2011 r., sprawnie wkomponowuje się we wskazany trend aktywności wydawniczej poświęconej historii kobiet. Stowarzyszenie, które w dużej części tworzone jest przez akademików, dysponuje swym wydawnictwem (Wydawnictwo Humanica, www.wydawnictwo.isk. bialystok.pl) i periodykiem naukowym („Czasopismo Naukowe ISK”, www.czasopismo.isk.bialystok.pl), współpracuje ze środowiskiem naukowym $z$ kraju i zagranicy, podejmuje przedsięwzięcia wydawnicze, upowszechnia wyniki badań naukowych tematyki kobiecej i realizuje projekty (naukowe, edukacyjne oraz kulturalne) o zasięgu regionalnym, krajowym i międzynarodowym. Inicjatywy Instytutu kierowane są do społeczności uniwersyteckiej oraz pozaakademickiej, zainteresowanej zwłaszcza szeroko rozumiana problematyka miejsca kobiet w społeczeństwie, zarówno w dziejach, jak i współczesności.

Wśród celów statutowych Instytutu Studiów Kobiecych znajduja się m.in.:

- prowadzenie, upowszechnianie i popularyzacja badań naukowych dotyczących historii kobiet, w tym ich udziału w życiu publicznym, miejsca w społeczeństwie w dziejach i współczesności oraz ich wkładu w dziedzictwo kulturowe Polski, Europy i świata;

- realizacja i koordynowanie projektów naukowych, edukacyjnych i kulturalnych upowszechniajacych i popularyzujacych pamięć o dziejach kobiet w kraju i za granica;

3 Według danych na 20.11.2019 r. 
- inicjowanie i upowszechnianie badań naukowych prowadzonych przez kobiety w różnych dyscyplinach nauki oraz popularyzacja i promocja wkładu kobiet w rozwój nauki, kultury, edukacji, oświaty ${ }^{4}$.

Działalność w zakresie badań naukowych historii kobiet i ich upowszechniania, w przypadku Instytutu Studiów Kobiecych w latach 2017-2019, należy podzielić na dwa podstawowe obszary: tematyczne badania naukowe inicjowane i realizowane przez stowarzyszenie oraz przedsięwzięcia popularyzacji wyników badań naukowych nad dziejami kobiet. Do pierwszej kategorii można zaliczyć opracowanie dwóch części słownika biograficznego kobiet kultury i utworzenie Ośrodka Badań Historii Kobiet. Poczet drugiego pola aktywności tworzą: organizowane profilowane konferencje naukowe, udział w zagranicznych wizytach studyjnych, rozwijajacy się periodyk naukowy oraz wydawnictwo stowarzyszenia.

W 2017 r. nakładem należącego do stowarzyszenia Wydawnictwa Humanica ukazał się Słownik biograficzny kobiet kultury. Białystok i województwo podlaskie, cz. I ${ }^{5}$. W pracy Małgorzaty Dajnowicz, Marcina Siedleckiego, Wiesława Wróbla zaprezentowano - jak czytamy w jej wstępie -,subiektywny zbiór życiorysów kobiet ze szczególnym uwzględnieniem wątków ich aktywności "w zakresie kultury" oraz wkładu w rozwój dziedzictwa kulturowego obszaru, z którym były zwiazane" ${ }^{\text {. W }}$ opracowaniu znalazło się dwadzieścia biogramów zestawionych chronologią życia, twórczości i aktywności bohaterek, począwszy od Aleksandry Wiesiołowskiej (ok. 1580-1645), fundatorki ważnych obiektów sakralnych przełomu „złotego” i „srebrnego” wieku I Rzeczypospolitej, po Annę Markowa (1932-2008), literatkę zwiazana z Białymstokiem w czasach współczesnych. Stopień rozpoznawalności poszczególnych bohaterek słownika w szerokim kręgu odbiorców jest bardzo różny. W publikacji znalazły się m.in., po pierwsze, Maria Konopnicka i Eliza Orzeszkowa, które przynależą do narodowego kanonu twórczyń kultury, po drugie, kobiety - symbole małych ojczyzn: Hanka Bielicka (Łomża), Izabela Branicka (Białystok, Bielsk Podlaski), po trzecie, kobiety, których działalność

\footnotetext{
4 Zapisy zawarte w rozdz. II § 6 pkt 3, 5, 16 Statutu Instytutu Studiów Kobiecych, zbiory własne.

5 Małgorzata Dajnowicz, Marcin Siedlecki, Wiesław Wróbel, Słownik biograficzny kobiet kultury. Białystok i województwo podlaskie, cz. I, (Białystok : Wydawnictwo Humanica, 2017), ss. 169.

6 Małgorzata Dajnowicz, „Wstęp”, w: Ibidem, 7.
} 
jest w województwie podlaskim znana wąskiemu gronu osób (Sofia Casanova, Placyda Bukowska). Na opis sylwetek składają się szczegółowe informacje faktograficzne, którym współtowarzyszą syntetyczne prezentacje życia wszystkich bohaterek. Biogramy zostały wzbogacone o ikonografię, materiały graficzne, które podnoszą walory przekazu.

W 2018 r. Instytut Studiów Kobiecych zaprezentował czytelnikom, zrecenzowany przez dr hab. Beatę Walenciuk-Dejneke, prof. UPH, oraz dr. hab. Adama Miodowskiego, prof. UwB, Słownik biograficzny kobiet kultury. Bialystok i województwo podlaskie, cz. II ${ }^{7}$. Celem prowadzonych badań naukowych, których zwieńczeniem stała się ww. publikacja, było opracowanie kolejnej grupy biogramów wyróżniających się osobowości kultury - kobiet „zanurzonych” w dziedzictwie podlaskim, a jednocześnie je tworzących. Na drugi tom słownika złożyło się ponownie dwadzieścia sylwetek kobiet związanych z Białymstokiem i Podlasiem, Łomżą i północno-wschodnim Mazowszem oraz Suwałkami i Suwalszczyzna. Przedstawione w wydawnictwie osoby kształtowały oblicze kulturowe swych małych ojczyzn, ale też kraju i społeczności międzynarodowej. W opracowaniu przeważaja „rzeczniczki kultury duchowej (piśmiennictwa, w pojedynczych przypadkach sztuki), niektóre były zwiąane $z$ kultura społeczną (określając i wyznaczając normy moralne, obyczajowe, społeczne czy ideologiczne), inne uczestniczyły w kreowaniu kultury politycznej (kształtując wzorce zachowań obywatelskich i politycznych), znalazły się też przedstawicielki kultury materialnej (ze śladami wytworów rzeczowych jako przejawów ich działalności)"8. Wśród biogramów w ujęciu regionalnym odnajdziemy cztery reprezentantki Suwalszczyzny, w tym Aleksandrę Piłsudska, komendantkę oddziału wywiadowczo-kurierskiego I Brygady Legionów Polskich, promotorkę sprawy polskiej po 1939 r. na emigracji w Londynie. $Z$ regionem podlaskim wiąały się losy siedmiu bohaterek tomu, np. urodzonej w Supraślu Józefiny Zachert, aktywnej $\mathrm{w}$ wielu organizacjach kulturalnych i dobroczynnych przełomu XIX i XX stulecia. W opracowaniu omówiono ponadto działalność dziewięciu kobiet ziemi łomżyńskiej, w tym aktywność Marii Moczydłowskiej, działaczki ruchu spółdzielczego, posłanki na Sejm II Rzeczypospolitej.

7 Małgorzata Dajnowicz, Maria Bauchrowicz-Tocka, Wiesław Wróbel, Słownik biograficzny kobiet kultury. Białystok i województwo podlaskie, cz. II, (Białystok : Wydawnictwo Humanica, 2018), ss. 152.

8 Małgorzata Dajnowicz, „Wstęp”, w: Ibidem, 7. 
W 2019 r. Instytut Studiów Kobiecych otrzymał grant na utworzenie Ośrodka Badań Historii Kobiet $z$ programu „DIALOG”, finansowanego ze środków Ministerstwa Nauki i Szkolnictwa Wyższego. Program ten dotuje działania w trzech obszarach: „Doskonałość naukowa”, „Nauka dla innowacyjności”, „Humanistyka dla rozwoju”. Celem instrumentu jest wsparcie działań służących budowaniu współpracy i trwałych relacji między podmiotami działającymi w obszarze nauki a tymi w sferze społeczno-gospodarczej. Program jest ukierunkowany m.in. na wspieranie działań zmierzających do implementacji rozwiazań prowadzących do podwyższania jakości i konkurencyjności prowadzonych badań naukowych, wzmocnienie potencjału oraz stymulowanie rozwoju nauk humanistycznych i społecznych. Środki finansowe pozyskane przez Instytut Studiów Kobiecych w ramach grantu umożliwiły inkubację Białostockiej Szkoły Historii Kobiet, w ramach której organizowane sa cykliczne warsztaty naukowe prowadzone przez badaczy historii kobiet, skierowane do studentów, doktorantów, a także zainteresowanych szeroko rozumianą kwestią kobiecą.

Jednym $z$ narzędzi upowszechniania przez Instytut Studiów Kobiecych badań nad historia kobiet stały się zagraniczne wizyty studyjne. W 2017 r. na Uniwersytecie Islandzkim w Reykjaviku omawiano z partnerami pomysły współpracy w obszarze kultury. W celu przedstawienia badań prowadzonych w Polsce na temat wkładu kobiet polskich w rozwój oblicza społecznego i kulturowego Polski w XX w. prof. Małgorzata Dajnowicz przedstawiła wykład dotyczacy udziału kobiet w życiu publicznym, w tym w polskiej kulturze XX w. Po wykładzie odbyła się dyskusja na temat treści wystapienia oraz aktywności kulturalnej kobiet w Polsce i na Islandii. Kolejne wydarzenie studyjne zorganizowane zostało w norweskich placówkach, również w 2017 r. Przedstawiciele Stowarzyszenia ISK zostali zapoznani $z$ bogatymi zbiorami muzealnymi dotyczacymi głównie historii kobiet Norwegii, znajdującymi się w Bibliotece Narodowej w Oslo i Muzeum Kobiet w Kongsvinger (niespełna 20-tys. miasto, założone w XVII w., zlokalizowane przy granicy ze Szwecja). Zaobserwowane dobre praktyki organizacji partnerskich zostały przeniesione na grunt działalności statutowej Stowarzyszenia ISK w zakresie „budowania pamięci o kobietach” w kolejnych projektach organizacji.

9 Zob. Komunikat Ministra Nauki i Szkolnictwa Wyższego z dnia 23.01.2019 r. o ustanowieniu programu pod nazwa „DIALOG”, www.gov.pl/web/nauka/dialog. 
W 2018 i 2019 r. Instytut Studiów Kobiecych realizował dwie umowy finansowane ze środków Ministerstwa Nauki i Szkolnictwa Wyższego przeznaczonych na działalność upowszechniająca naukę ${ }^{10}$. Komponent DUN (działalność upowszechniająca naukę) służy realizacji zadań wspierających rozwój polskiej nauki przez upowszechnianie, promocję i popularyzację wyników działalności badawczo-rozwojowej, innowacyjnej i wynalazczej. Stowarzyszenie ISK środki pozyskane w ramach grantów naukowych przeznaczyło m.in. na organizację kolejnych konferencji naukowych z cyklu „Polityka i politycy w prasie XX i XXI wieku”.

Gros potencjału i zaangażowania członków Instytutu Studiów Kobiecych w analizowanym okresie wykorzystane zostały do przygotowania i przeprowadzenia dużych konferencji naukowych poświęconych tematyce kobiecej. W 2017 r. ISK pod patronatem wojewody podlaskiego Bohdana Paszkowskiego, rektora Uniwersytetu w Białymstoku prof. dr. hab. Roberta Ciborowskiego oraz prezydenta miasta Białegostoku prof. dr. hab. Tadeusza Truskolaskiego zorganizował II ogólnopolską konferencję naukowa $z$ cyklu „Polityka i politycy w prasie XX i XXI wieku” pt. „Prasa organizacji politycznych". W konferencji wzięli udział specjaliści z zakresu historii prasy, w tym również prasoznawcy i politolodzy, m.in. z Uniwersytetu Warszawskiego, Uniwersytetu Jagiellońskiego, Uniwersytetu Mikołaja Kopernika w Toruniu, Uniwersytetu Marii Curie-Skłodowskiej w Lublinie, Uniwersytetu Łódzkiego, Uniwersytetu w Białymstoku. Efektem dyskusji naukowej stała się publikacja pokonferencyjna pt. Polityka i politycy $w$ prasie XX $i$ XXI wieku. Prasa organizacji politycznych wydana pod redakcja Małgorzaty Dajnowicz i Adama Miodowskiego ${ }^{11}$. W ponad 400-stronicowym tomie znalazło się dwadzieścia sześć artykułów poświęconych prasie organizacji politycznych - organizacji traktowanych sensu largo: instytucji politycznych państwa, partii politycznych, masowych ruchów społecznych, upolitycznionych struktur niepodległościowych, podmiotów pozarządowych (NGO). W ujęciu chronologicznym zakres poruszanych zagadnień rozciaga się na przestrzeni ponad stu dwudziestu lat. W publikacji odnajdziemy np. tekst Witolda Wojdyły nt. funkcjonowania „Gazety Robotniczej”, organu prasowego Towarzystwa Socjalistów Polskich w Berlinie, w pierwszych latach ostatniej dekady XIX w. Na drugim

10 Umowa nr 809/P-DUN/2018, umowa nr 729/P-DUN/2019.

11 Małgorzata Dajnowicz, Adam Miodowski (red.), Polityka i politycy w prasie XX i XXI wieku. Prasa organizacji politycznych, (Białystok: Wydawnictwo Humanica, 2017). 
krańcu czasu możemy się zapoznać $z$ analiza prasoznawczą wykonaną przez Małgorzatę Wrześniewska, a poświęconą czasopismu „Niedziela” za rok 2016. Największa liczba prac (siedem) została zebrana w rozdziale Rola kobiecej prasy spoleczno-politycznej i jej publicystek $w$ aktywizacji kobiet $w X X$ wieku. W tej części pojawił się m.in. tekst Joanny Dufrat, $z$ którego dowiemy się, iż „na tle ogólnego obrazu czasopism kobiecych okresu międzywojennego organy prasowe żeńskich organizacji politycznych odznaczały się ponadprzeciętnym poziomem: nie tylko podą̇ały za zainteresowaniami swoich czytelniczek, ale przede wszystkim starały się te zainteresowania kreować, edukujac, przekonując i zachęcając do politycznej aktywności" ${ }^{\prime 2}$. Ważne zagadnienia zostały wyeksponowane w rozdziale na temat prasy społeczno-politycznej diaspory polskiej w Europie. W artykule Krzysztofa Buchowskiego nt. czasopism polskiej mniejszości narodowej w międzywojennej Republice Litewskiej przeczytamy, że „polska prasa, podobnie jak wydawnictwa litewskie, podlegała ścisłej cenzurze prewencyjnej ... "Dziennik Kowieński» po zakwestionowanych notatkach i artykułach często wychodził z "białymi plamami»"13.

W roku obchodów stulecia odzyskania niepodległości RP stowarzyszenie kierowane przez prof. dr hab. Małgorzatę Dajnowicz zorganizowało, we współpracy z Zakładem Ruchów Społecznych i Politycznych Wydziału Historyczno-Socjologicznego UwB, międzynarodowa konferencję naukowa, trzecią $z$ cyklu „Polityka i politycy w prasie XX i XXI wieku”, tym razem $z$ myśla przewodnia wydarzenia „Polityka w prasie kobiecej”. Internacjonalne spotkanie naukowe umożliwiło przeprowadzenie dyskusji na temat miejsca polityki w periodykach kobiecych (polskich i zagranicznych) XX i XXI w. Na konferencje przybyli prelegenci z Polski, Litwy, Białorusi i Czech. Efektem obrad stała się monografia naukowa pt. Polityka i politycy w prasie XX $i$ XXI wieku. Polityka w prasie kobiecej pod red. Małgorzaty Dajnowicz i Adama Miodowskiego ${ }^{14}$.

W 2018 r. Stowarzyszenie ISK już po raz drugi zostało współorganizatorem prestiżowej konferencji naukowej Komisji Historii Kobiet Ko-

12 Joanna Dufrat, „Prasa politycznych organizacji kobiecych w Polsce w latach 19171939", w: Ibidem, 48.

${ }^{13}$ Krzysztof Buchowski, „Czasopisma polskiej mniejszości narodowej w międzywojennej Republice Litewskiej”, w: Ibidem, 252-253.

14 Małgorzata Dajnowicz, Adam Miodowski (red.), Polityka i politycy w prasie XX i XXI wieku. Polityka w prasie kobiecej, (Białystok : Wydawnictwo Humanica, 2018). 
mitetu Nauk Historycznych PAN ${ }^{15}$ pt. „Strategie małżeńskie pań i panów na przestrzeni wieków". Udział w konferencji zgłosili specjaliści z zakresu badań nad historią kobiet, w tym historycy, literaturoznawcy, socjolodzy, m.in. z UW, UJ, UMK, UMCS, UŁ, UWr, USz, UwB. Patronatem naukowym konferencję objęli wojewoda podlaski Bohdan Paszkowski i rektor Uniwersytetu w Białymstoku prof. dr hab. Robert Ciborowski. Trzeci dzień obrad zakończył się wizytą studyjną w Tykocinie i Knyszynie „szlakiem zabytków Podlasia”, zorganizowana przez Podlaski Wojewódzki Urząd Ochrony Zabytków.

W 2019 r. ISK gościł uczestników IV ogólnopolskiej konferencji naukowej z serii „Polityka i politycy w prasie XX i XXI wieku”. Temat przewodni obrad pt. „Kobiety i wybory parlamentarne” ukierunkował wymianę doświadczeń odnośnie do stanu badań nad miejscem kobiet w polityce w ciagu dziejów, w szczególności ich udziału w wyborach. W konferencji uczestniczyli prelegenci $z$ całego kraju, m.in. $z$ Lublina, Kielc, Krakowa, Wrocławia, Warszawy i Szczecina. Wydarzenie zostało objęte patronatem wojewody podlaskiego Bohdana Paszkowskiego, marszałka województwa podlaskiego Artura Kosickiego oraz rektora Uniwersytetu w Białymstoku prof. dr. hab. Roberta Ciborowskiego. Wydarzeniu naukowemu towarzyszyła wystawa „PODWÓJNIE WOLNE. Prawa polityczne kobiet 1918" zorganizowana przez Instytut Pileckiego przy współpracy z Uniwersytetem w Białymstoku i Instytutem Studiów Kobiecych. Tytuł ekspozycji podkreśla, że rok 1918 był dla Polek nie tylko rokiem odzyskania niepodległości, lecz także momentem uzyskania praw obywatelskich ${ }^{16}$. Chrześcijańskie demokratki, feministki i rewolucjonistki przez wiele lat działały na rzecz równych praw, jak również odzyskania przez Polskę niepodległości. Aktem przełomowym tych starań było doprowadzenie do przyznania Polkom praw wyborczych w 1918 r.

\footnotetext{
${ }_{15}$ Komisja Historii Kobiet rozpoczęła działalność w 1996 r. z inicjatywy i pod przewodnictwem prof. Anny Żarnowskiej. Od początku celem gremium było stworzenie forum dyskusji o dziejach kobiet, co motywowane było m.in. chęcia zapoznania i wprowadzenia w polskich badaniach historycznych nowej metodologii. Zob. www.khk.pan.pl/index. php?option=com_content\&view=article\&id=59\&Itemid.

16 „Podwójnie wolne” - to słowa jednej z sufrażystek komentującej ukazanie się 28.11.1918 r. dekretu naczelnika państwa dotyczacego nadania czynnych i biernych praw wyborczych kobietom (co postawiło Polskę w szeregu najbardziej demokratycznych i nowoczesnych państw Europy). Fraza ta najtrafniej opisuje doświadczenie Polek - wolnych dzięki odzyskaniu niepodległości i wolnych w prawach obywatelskich. Zob. https://instytutpileckiego.pl/pl/ wystawy/podwojnie-wolne-prawa-polityczne-kobiet-1918-wystawa.
} 
Sukcesem Instytutu Studiów Kobiecych jest rozwój periodyku wydawniczego - „Czasopisma Naukowego ISK”. Powstało w 2016 r. $z$ inicjatywy pracowników naukowych związanych ze stowarzyszeniem oraz Wydziałem Historii i Stosunków Międzynarodowych Uniwersytetu w Białymstoku. Wydane numery periodyku pozwoliły włączyć się środowisku stowarzyszenia oraz jego współpracowników i gości do dyskusji naukowej nad problematyką kobieca. Na łamach czasopisma sa upowszechniane osiagnięcia naukowe $z$ zakresu historii, nauk o polityce, prawa, socjologii, kulturoznawstwa i literaturoznawstwa. Spoiwem łaczacym prezentowana tematyke jest problematyka kobiet ukazywana przez perspektywę nauk humanistycznych i społecznych ${ }^{17}$. „Czasopismo Naukowe ISK” w 2017 r. zostało poddane ocenie parametrycznej przez ekspertów Index Copernicus. Na podstawie weryfikacji informacji $z$ ankiety czasopisma i analizy wydań periodyku z 2016 r. eksperci Index Copernicus wyznaczyli wartość wskaźnika ICV (Index Copernicus Value) w wysokości 57,41, a efektem stało się wpisanie na listę czasopism naukowych ICI Journals Master List $2016^{18}$. Na podstawie weryfikacji informacji z ankiety czasopisma i analizy wydań czasopisma z 2018 r. eksperci Index Copernicus wyznaczyli wartość wskaźnika ICV (Index Copernicus Value) za rok 2018 w wysokości 77,83'19. W Radzie Naukowej czasopisma zasiadaja m.in. prof. Elena Gapova (Western Michigan University, USA), prof. Jolanta Chwastyk-Kowalczyk (Uniwersytet Jana Kochanowskiego w Kielcach) czy prof. Virginija Jurènienė (Vilnius University, Litwa). W marcu 2019 r. minister nauki i szkolnictwa wyższego ustalił listę czasopism finansowanych w ramach projektu „Wsparcie dla czasopism naukowych” - „Czasopismo Naukowe ISK” znalazło się na niej wśród periodyków reprezentujących historię. Ponadto w 2019 r. czasopismo znalazło się w ważnym Wykazie czasopism punktowanych

\footnotetext{
17 www.czasopismo.isk.bialystok.pl.

18 ICI Journals Master List to międzynarodowa baza indeksacyjna czasopism naukowych, w ramach której każdego roku, od 20 lat, oceniane są zgłoszone periodyki. Warunkiem indeksacji jest pozytywne przejście wielowymiarowej oceny parametrycznej opartej na przeszło 100 kryteriach. Periodyki, które spełnia zarówno formalne kryteria, jak i wstępne warunki indeksacji, otrzymują - ważny przez rok - wskaźnik ICV (Index Copernicus Value), będący odzwierciedleniem poziomu rozwoju czasopisma oraz siły jego oddziaływania na świat nauki. Baza ICI Journals Master List jest jedyna polska globalna marka w nauce. Zob. https://indexcopernicus.com/index.php/ pl/parametryzacja-menu/ journals-master-list.

19 www.czasopismo.isk.bialystok.pl/\#rada.
} 
i recenzowanych materiałów $z$ konferencji międzynarodowych, opublikowanym przez Ministerstwo Nauki i Szkolnictwa Wyższego, a będacym najnowszym narzędziem reformy szkolnictwa wyższego i nauki, która diametralnie zmienia polski system ewaluacji osiagnieć pracowników naukowych. „Czasopismo Naukowe ISK” ma przypisane następujące dyscypliny naukowe: historia, nauki o kulturze i religii, nauki o bezpieczeństwie, nauki prawne, nauki socjologiczne oraz liczbę punktów $20^{20}$.

\section{Bibliografia}

\section{Źródła:}

Komunikat Ministra Nauki i Szkolnictwa Wyższego z dnia 23 stycznia 2019 r. o ustanowieniu programu pod nazwą „DIALOG”, www.gov.pl/ web/nauka/dialog

Statut Instytutu Studiów Kobiecych

Umowa nr 809/P-DUN/2018

Umowa nr 729/P-DUN/2019

Wykaz czasopism naukowych i recenzowanych materiałów z konferencji międzynarodowych, zał. do Komunikatu Ministra Nauki i Szkolnictwa Wyższego z dnia 31 lipca 2019 r., www.bip.nauka.gov.pl/g2/oryginal/ 2019_08/a07248ec34e343035b433bb 61f39c053.pdf

\section{Opracowania:}

Buchowski, Krzysztof. „Czasopisma polskiej mniejszości narodowej w międzywojennej Republice Litewskiej”, w: Małgorzata Dajnowicz, Adam Miodowski (red.), Polityka i politycy w prasie XX i XXI wieku. Prasa organizacji politycznych, (Białystok : Wydawnictwo Humanica, 2017), 249-257. ISBN 978-83-946177-3-8.

Dajnowicz, Małgorzata, Miodowski, Adam (red.). Polityka i politycy w prasie XX i XXI wieku. Prasa organizacji politycznych, (Białystok: Wydawnictwo Humanica, 2017). ISBN 978-83-946177-3-8.

20 Zob. pozycja nr 27806 Wykazu czasopism naukowych i recenzowanych materiałów z konferencji międzynarodowych, zał. do Komunikatu Ministra Nauki i Szkolnictwa Wyższego $z$ dnia 31.07.2019 r., www.bip.nauka.gov.pl/g2/oryginal/2019_08/a07248ec34e343035b433bb 61f39c053.pdf. 
Dajnowicz, Małgorzata, Miodowski, Adam (red.). Polityka i politycy w prasie XX i XXI wieku. Polityka w prasie kobiecej, (Białystok : Wydawnictwo Humanica, 2018). ISBN 978-83-7431-561-6.

Dajnowicz, Małgorzata, Siedlecki, Marcin, Wróbel, Wiesław. Słownik biograficzny kobiet kultury. Białystok i województwo podlaskie, cz. I, (Białystok : Wydawnictwo Humanica, 2017). ISBN 978-83-946177-2-1.

Dajnowicz, Małgorzata, Bauchrowicz-Tocka, Maria, Wróbel, Wiesław. Słownik biograficzny kobiet kultury. Białystok i województwo podlaskie, cz. II, (Białystok : Wydawnictwo Humanica, 2018). ISBN 978-83-946177-6-9.

Dufrat, Joanna. „Prasa politycznych organizacji kobiecych w Polsce w latach 1917-1939”, w: Małgorzata Dajnowicz, Adam Miodowski (red.), Polityka i politycy w prasie XX $i$ XXI wieku. Prasa organizacji politycznych, (Białystok: Wydawnictwo Humanica, 2017), 31-48. ISBN 978-83-946177-3-8. 